\title{
Investigation of the Awareness and Habits of Secondary School Students about Cleanliness and Hygiene from Various Variables
}

\author{
Ebru Yılmazel Çelik ${ }^{1} \&$ Zeynep Yüce ${ }^{2}$ \\ ${ }^{1}$ Graduate School of Natural and Applied Sciences, Kafkas University, Kars, Turkey \\ ${ }^{2}$ Faculty of Education, Kafkas University, Kars, Turkey \\ Correspondence: Ebru Yılmazel Çelik, Mathematics and Science Education, Graduate School of Natural and \\ Applied Sciences, Kafkas University, Kars, Turkey.
}

Received: November 14, 2018

doi:10.5539/ies.v12n4p173

\author{
Accepted: December 15, 2018 Online Published: March 25, 2019 \\ URL: https://doi.org/10.5539/ies.v12n4p173
}

\begin{abstract}
Cleanliness, hygiene and personal hygiene habits have an extremely important place in maintaining and developing an individual's physical and spiritual health. In contrast, it has been observed that research on student behaviour for cleaning and hygiene applications has been limited in the literature. In this case, "What are the cleaning and hygiene habits of students?" It has emerged as a necessity to answer the question. In this study, mixed blending method has been used. The study group consisted of 1300 students, studying in 12 different secondary schools in the city of Kars. In order to collect data, personal information form, "Personal Cleansing and Hygiene Habits Scale" developed by the researcher and open-ended questions were used. It was observed that the general cleaning and hygiene levels of the students were not statistically significantly different according to gender variables $(\mathrm{p}>.05)$. In terms of the personal hygiene and hygiene habits of the students' significant differences have been found according to their parents' education status, the number of individuals in their families and the level of their education. Significant differences have been found in terms of the personal hygiene and hygiene habits of the students according to their parents' education status, the number of individuals in their families and the level of their education $(\mathrm{p}<.05)$. In addition, the students' answers to open-ended questions have been seen to consider that they are largely used for cleaning and hygiene concepts, and that dirty-stained non-polluted is hygienic.
\end{abstract}

Keywords: science literacy, cleanliness, hygiene, health, secondary school student

\section{Introduction}

The individuals who make up communities need to maintain and develop their health in order to sustain their generations. Healthy growth of a generation is also necessary to accelerate the productivity and development of countries. The protection and development of health is ensured by eliminating all disease-constructive factors. Many of the disease-forming factors are spread through cross or direct contamination. In the control of many infectious diseases, personal hygiene habits are known to be important. With weak personal hygiene practices, all people are negatively affected. But the most vulnerable group in all individuals constitutes school age children (WHO, 1996).

The most important reasons for the rapid spread of infectious diseases are collective life (Şanll, Topyürek \& Güngen, 2002). In particular, public living areas such as dormitories and schools are very risky environments in terms of hygiene problems and infections (Kitiş \& Bilgili, 2011). Therefore, especially the school environment directly affects the health of the physical and social surroundings (Allison et al., 2007). Schools are a public living area where children spend a large portion of their day and are also risky for infections due to insufficient basic personal hygiene knowledge and skills. Children are very prone to infection by touching everything with their hands, being in close contact with other children, and taking their hands to their mouths. They also have a greater risk of infection because their immune systems are not fully developed and their vaccination is not completed (Kitiş \& Bilgili, 2011).

One of the most important factors affecting school success is the health of the child. Various health problems seen during the school period negatively affects learning. Ear, nose and respiratory infections, influenza, pneumonia and dental diseases are the main diseases seen in children of school age (Igoe \& Speer, 1996). The problems caused by deficiencies in general body and oral hygiene during the school age is another important problem that 
is common in these age groups. In many studies on this issue, hygiene deficiencies in various ratios have been determined and the relationship of this issue to health problems is observed (Güler \& Kubilay, 2004).

Tooth decay, throat diseases, parasitosis, allergies, skin diseases, ear diseases, visual impairments in the school age children in Turkey as a result of the screening was determined to be one of the most common problems. In addition, $30 \%$ of the school age children have anemia and $30-50 \%$ of them have parasites. All of these findings have been determined that school age children formed a significant risk group in the society (Güler \& Kubilay, 2004).

In order to improve health habits, childhood is a very suitable period compared to other developmental periods. Therefore, the school is the most comprehensive place where the foundations of a health-related society are laid. Students who spend much of their time at school will be given health education effectively and will be able to learn the hygiene and cleanliness habits of the child who is always open to change. After that, the child will undertake a great task in the community with information he learns and shares (Bebiş, 1997).

The first and most important rule of health protection is cleanliness. Cleaning is defined as the removal of visible contaminants from the environment. Hygiene is the protection of the healthy environment and removal of the environment from germs (Bilici, Uyar, Beyhan, \& Sağlam, 2008; Kahveci \& Demirtaş, 2012). With the full provision of hygiene, individuals are free from pathogenic microorganisms and parasites and do not infect any infectious disease to others (Kahveci \& Demirtaş, 2012).

One of the most important hygiene applications is personal hygiene practices (Önsüz \& Hıdıroğlu, 2008). Personal hygiene includes all of the "self care practices" that people do in order to maintain their own health (Yetkin \& Yiğitbaş, 2008). Keeping the person's own body and clothing away from dirt and cleaning is considered the most basic purpose of personal hygiene. This will ensure that the body is always healthy.

Personal hygiene measures will prevent many diseases, especially infectious diseases. Among these measures (Kaya et al., 2006);

- Hair cleaning and care,

- Face, eye and ear cleaning,

- Oral and dental care,

- Regular bathing,

- Hand and nail cleaning and maintenance,

- Foot cleaning,

- Use of clean laundry and clothing,

- Personalized towel, comb, washing, toothbrush and nail clippers can be counted.

It is also important for personal hygiene not only to clean the body, but also to clean the environment.

In this study, the habits of secondary school students regarding cleaning and hygiene practices were examined according to some variables. In line with this aim, it is aimed to determine the attitudes of secondary school students towards hygiene and cleaning practices, which is a dimension of science literacy education, to reveal their knowledge about personal hygiene habits and to raise awareness.

\section{Method}

\subsection{Research Design}

In this study, a mixed scanning model consisting of quantitative and qualitative questions was used.

\subsection{Study Group}

The research was carried out with students studying in 12 different secondary schools in the city center of Kars in 2016-2017 academic year. A total of 1300 secondary school students, including 712 girls and 588 boys, participated in the study. 347 of the participants were grade 5, 338 were in grade 6, 298 were in grade 7 and 317 were in grade 8.

\subsection{Data Collection Tools}

In this study, personal information form, personal hygiene habits scale and open-ended questions were used.

\subsubsection{Personal Information Form}

The personal information form is divided into two parts. The first part consists of students to recognize, the second 
part consists of yes/no and students' personal information about cleaning and hygiene.

\subsubsection{Personal Cleaning and Hygiene Habits Scale}

This section was developed to determine the hygiene and cleanliness habits of secondary school students. In this context, similar researches have been identified by conducting a literature review on the subject (Arat, 2013; Aydın, 1996; Bebiş, 1997; Balaban, 2011; Eraslan, 2009; Kahveci \& Demirtaş, 2012; Karadon, 2010; Karaoğlu \& Pehlivan, 1997; Kalınc1, 2006; Şimşek, 2012; Tartaç, 2007). Based on the findings, 120 question-pool was established. The substances created were presented in the opinion of two science education and a biology expert, and at the end, 35 material personal cleansing and hygiene habits candidate scale was developed. All items on the candidate scale are in a positive direction. In this case, those who select the Always option 3 points, the occasional option 2 points and never select the option was evaluated by 1 point. 237 students participated in the pre-application of the candidate scale. The validity and reliability of the developed candidate scale has been examined. Scale has been studied in terms of scope and structure validity. In this context, factor and substance analysis was carried out for the candidate scale consisting of 35 items. Items that were not loaded on any factors, factor loads below .30, loaded on more than one factor, the difference between factor loadings were determined to be less than .10 or 24 items that the contribution to the explained variance was low was excluded from the scale. The total variance explained by the 11 item scale, which is limited by a single factor, is $49 \%$. The variance explained in single factor scales can be seen as $30 \%$ or more (Büyüköztürk, 2017). The item load values of the single factor scale range from .47 to .83 . Item total correlations are examined for the reliability of the scale. An unbound t-test was used to determine the difference between the lower $27 \%$ and the top $27 \%$ of the group's scores. The lower $27 \%$ and the top $27 \%$ have 64 students in the group. The t-test was made meaningful. The Cronbach Alpha coefficient of the Spearman Brown .90 and 11 items was found to be .89 . In line with these results, the reliability of the 11 item scale was found quite high.

\subsubsection{Open-Ended Questions Section}

In order to express the answers to quantitative questions from secondary school students and to find out whether the data obtained will support each other "What do you think of cleanliness?", "What do you think of hygiene?", "What do you think of personal hygiene?" and "What kind of applications do you do to ensure your personal hygiene in one day?" have been added.

\subsection{Data Analysis}

The analysis of the data gained in the course of the study was conducted using SPSS 22 program. Total scores of the data were not found to show normal distribution and non-parametric analyzes were used. Mann Whitney-U and Kruskal Wallis-H tests were conducted. The significance level is set to $\mathrm{p}<.05$.

\section{Results}

Descriptive statistics of students about cleaning and hygiene levels are listed in Table 1.

Table 1. Descriptive statistical results for cleanliness and hygiene levels

\begin{tabular}{|c|c|c|c|}
\hline Questions & Answers & $\mathrm{f}$ & $\%$ \\
\hline \multirow{2}{*}{ Does water flow regularly in your home? } & Yes & 1130 & 86.9 \\
\hline & No & 170 & 13.1 \\
\hline \multirow{2}{*}{ Are your bedrooms and rooms cleaned regularly in your home? } & Yes & 1268 & 97.5 \\
\hline & No & 32 & 2.5 \\
\hline \multirow{2}{*}{ Do your family elders warn you to wash your hands? } & Yes & 1238 & 95.2 \\
\hline & No & 62 & 4.8 \\
\hline \multirow{2}{*}{ Do your family elders warn you to cut your nails? } & Yes & 1244 & 95.7 \\
\hline & No & 56 & 4.3 \\
\hline \multirow{2}{*}{ Do your family elders warn you to wash your feet? } & Yes & 1065 & 81.9 \\
\hline & No & 235 & 18.1 \\
\hline \multirow{2}{*}{ Do your family elders warn you to wash your face? } & Yes & 1213 & 93.3 \\
\hline & No & 87 & 6.7 \\
\hline \multirow{2}{*}{ Do your family elders warn you to brush your teeth? } & Yes & 1174 & 90.3 \\
\hline & No & 126 & 9.7 \\
\hline \multirow{2}{*}{ Does your parents warn you to take a bath? } & Yes & 1192 & 91.7 \\
\hline & No & 108 & 8.3 \\
\hline
\end{tabular}




\begin{tabular}{|c|c|c|c|}
\hline \multirow{2}{*}{ Do you use the same towel at home, including all of your family members? } & Yes & 277 & 21.3 \\
\hline & No & 1023 & 78.7 \\
\hline \multirow{2}{*}{ Have you been given an education in your school regarding cleanliness and hygiene issues? } & Yes & 609 & 46.8 \\
\hline & No & 691 & 53.2 \\
\hline \multirow{2}{*}{$\begin{array}{l}\text { Do you think this training is adequate if you have been given an education regarding cleanliness and hygiene } \\
\text { issues? }\end{array}$} & Yes & 310 & 50.9 \\
\hline & No & 299 & 49.1 \\
\hline \multirow{2}{*}{ Do you want to be trained if you have not been trained in hygiene and hygiene issues? } & Yes & 618 & 89.4 \\
\hline & No & 73 & 10.6 \\
\hline
\end{tabular}

Table 1 when examined, it is observed that the majority of the students care about cleaning and hygiene at home and warned by their families about cleaning and hygiene. It is observed that nearly half of the students are educated in cleaning and hygiene in their schools and that the students are not satisfied with the education they receive. $89.4 \%$ of the students who do not receive education on cleanliness and hygiene in their schools want education on cleanliness and hygiene in their schools.

The Mann Whitney-U test results of the personal hygiene and hygiene levels of the students according to their gender are shown in Table 2.

Table 2. Mann Whitney-U test results for personal cleansing and hygiene levels by gender

\begin{tabular}{cccccccc}
\hline Gender & $\mathrm{N}$ & $\mathrm{X}$ & $\mathrm{Ss}$ & Sequence average & Sequence total & $\mathrm{U}$ & $\mathrm{p}$ \\
\hline Male & 588 & 27.73 & 2.982 & 656.02 & 385740.5 & \multirow{2}{*}{206081.5} & \multirow{2}{*}{628} \\
Female & 712 & 27.61 & 3.050 & 645.94 & 459909.5 & & \\
\hline
\end{tabular}

Table 2 when examined, it is observed that the Mann Whitney-U test for the personal hygiene and hygiene levels of the students according to their gender did not differ significantly ( $p>.05)$.

The results of the Kruskal Wallis-H test of the students' attitudes towards personal cleansing and hygiene levels according to the classes they are studying are in Table 3.

Table 3. Kruskal Wallis-H test results regarding the personal cleaning and hygiene levels according to their class

\begin{tabular}{ccccccc}
\hline Class & $\mathrm{n}$ & $\mathrm{X}$ & $\mathrm{Ss}$ & Sequence average & $\chi^{2}$ & $\mathrm{p}$ \\
\hline 5.class & 347 & 27.50 & 2.920 & 624.42 & & \\
6.class & 338 & 27.88 & 2.783 & 669.94 & & \\
7.class & 298 & 28.04 & 3.109 & 707.14 & 14.175 & .003 \\
8.class & 317 & 27.27 & 3.227 & 605.07 & & \\
\hline
\end{tabular}

Table 3 when examined, Kruskal Wallis-H test results for personal hygiene and hygiene according to the classes studied by the students were statistically significantly different $(\mathrm{p}<.05)$. Mann Whitney-U test was carried out to investigate the source of differences observed in the students and it was determined that the level of Class 7 were significantly higher than Class 5 , the level of Class 6,7 were significantly higher than Class 8 on personal hygiene and cleanliness.

Kruskal Wallis-H test results for personal hygiene and hygiene levels of the mothers according to their mothers' educational status are listed in Table 4.

Table 4. Kruskal Wallis-H test results on personal hygiene and hygiene levels according to their mother's educational status

\begin{tabular}{ccccccc}
\hline Education status & $\mathrm{n}$ & $\mathrm{X}$ & $\mathrm{Ss}$ & Sequence average & $\chi^{2}$ & $\mathrm{p}$ \\
\hline Not literate & 88 & 26.92 & 2.960 & 542.31 & & \\
Primary school & 362 & 27.16 & 3.357 & 599.52 & & \\
Secondary school & 460 & 28.11 & 2.904 & 710.06 & 26.434 & .000 \\
High school & 308 & 27.71 & 2.829 & 644.69 & & \\
University & 82 & 28.05 & 2.314 & 679.38 & & \\
\hline
\end{tabular}


When the Table 4 is examined, it is seen that the results of Kruskal Wallis-H test on the level of personal hygiene and hygiene of the mothers of the students differ significantly $(p<.05)$. In order to examine the origin of differences observed in students, Mann Whitney-U test was carried out, personal hygiene and hygiene levels of students whose mother graduated from secondary, high school and university were found to be significantly higher than those whose mother was illiterate and personal hygiene and hygiene levels of students whose mother graduated from secondary school were found to be significantly higher than those whose mother was graduated from primary, high school.

The results of the Kruskal Wallis-H test on the personal hygiene and hygiene levels of the fathers according to the educational status of their fathers are listed in Table 5.

Table 5. Kruskal Wallis-H test results for personal cleansing and hygiene levels according to the education status of their fathers

\begin{tabular}{ccccccc}
\hline Education status & $\mathrm{n}$ & $\mathrm{X}$ & $\mathrm{Ss}$ & Sequence average & $\chi^{2}$ & $\mathrm{p}$ \\
\hline Not literate & 35 & 25.14 & 3.405 & 367.80 & & \\
Primary school & 188 & 27.53 & 3.182 & 637.47 & & \\
Secondary school & 427 & 28.04 & 2.911 & 697.02 & 30.604 & .000 \\
High school & 474 & 27.47 & 2.982 & 623.41 & & \\
University & 176 & 27.92 & 2.847 & 680.73 & & \\
\hline
\end{tabular}

Table 5 when examined, it is observed that Kruskal Wallis-H test results for personal hygiene and cleaning were statistically significantly different according to the educational status of the students' fathers $(\mathrm{p}<.05)$. In order to examine the source of differences observed in students, Mann Whitney-U test was carried out and it was determined that the personal hygiene and hygiene levels of the students whose father graduated from primary school, secondary school, high school and university were significantly higher than the students whose father was illiterate and the personal hygiene and hygiene levels of the students whose father graduated from secondary school were significantly higher than the students whose father graduated from high school.

The results of the Kruskal Wallis-H test regarding the personal hygiene and hygiene levels according to the number of individuals of the students are given in Table 6 .

Table 6. Kruskal Wallis-H test results for personal hygiene and hygiene levels according to the number of individuals in their families

\begin{tabular}{ccccccc}
\hline Number of people & $\mathrm{n}$ & $\mathrm{X}$ & $\mathrm{Ss}$ & Sequence average & $\chi^{2}$ & $\mathrm{p}$ \\
\hline $2-4$ & 392 & 27.34 & 3.214 & 617.01 & & \\
$5-7$ & 768 & 27.76 & 2.909 & 658.86 & & \\
$8-10$ & 107 & 28.42 & 2.768 & 736.09 & 10.478 & .015 \\
$10+$ & 33 & 26.94 & 3.409 & 576.23 & & \\
\hline
\end{tabular}

Table 6 when examined, Kruskal Wallis-H test results for personal hygiene and hygiene were statistically significantly different according to the number of individuals in the family of the students $(\mathrm{p}<.05)$. Mann Whitney-U test was carried out to examine the origin of differences observed in students and it was found that the personal hygiene and hygiene levels of 8-10 individuals in the family were significantly higher than those of 2-4, 5-7 and $10+$ individuals in the family.

Mann Whitney-U test results for personal hygiene and hygiene levels according to the regular cleaning of bedrooms and other rooms in the students' homes took place in Table 7.

Table 7. Mann Whitney-U test results on personal hygiene and hygiene levels according to the regular cleaning of bedrooms and other rooms at home

\begin{tabular}{cccccccc}
\hline Situation & $\mathrm{N}$ & $\mathrm{X}$ & $\mathrm{Ss}$ & Sequence average & Sequence total & $\mathrm{U}$ & $\mathrm{p}$ \\
\hline Yes & 1268 & 27.70 & 3.005 & 654.35 & 829718.5 & & \\
No & 32 & 26.41 & 3.339 & 497.86 & 15931.5 & & .019 \\
\hline
\end{tabular}


Table 7 when analyzed, a statistically significant difference was found in Mann Whitney-U Test results of personal cleaning and hygiene levels of students who regularly cleaned bedrooms and other rooms in their homes $(p<.05)$. It has been observed that the students who regularly clean the rooms have a higher level of personal cleansing and hygiene.

Mann Whitney-U test results related to personal hygiene and hygiene levels are given in the Table 8 according to the condition that family elders have warned students about washing their feet feet.

Table 8. Mann Whitney-U test results for personal cleansing and hygiene levels according to the condition that family elders have warned themselves about washing their feet

\begin{tabular}{cccccccc}
\hline Situation & $\mathrm{N}$ & $\mathrm{X}$ & $\mathrm{Ss}$ & Sequence average & Sequence total & $\mathrm{U}$ & $\mathrm{p}$ \\
\hline Yes & 1065 & 27.87 & 2.997 & 677.78 & 721840.5 & & \\
No & 235 & 26.76 & 2.956 & 526.85 & 123809.5 & & .000 \\
\hline
\end{tabular}

Table 8 examined, a statistically significant difference was found according to the Mann Whitney-U test of the students who were warned to wash their feet by their parents $(p<.05)$. It has been observed that the students who are warned about washing their feet have a higher level of personal cleansing and hygiene.

The results of the Mann Whitney-U test for personal cleaning and hygiene levels are shown in Table 9 according to the condition that students' family elders warn themselves about brushing their teeth.

Table 9. Mann Whitney-U test results for personal cleaning and hygienic levels according to the condition that family elders warn themselves about brushing their teeth

\begin{tabular}{cccccccc}
\hline Situation & $\mathrm{N}$ & $\mathrm{X}$ & $\mathrm{Ss}$ & Sequence average & Sequence total & $\mathrm{U}$ & $\mathrm{p}$ \\
\hline Yes & 1174 & 27.74 & 3.008 & 660.37 & 775269.5 & \multirow{2}{*}{62379.5} & \multirow{2}{*}{004} \\
No & 126 & 27.00 & 3.054 & 558.58 & 70380.5 & & \\
\hline
\end{tabular}

Table 9 when examined, the personal hygiene and hygiene levels of the students, who were warned to brush their teeth by the family elders, were statistically significantly higher than the other students according to the Mann Whitney-U test results $(\mathrm{p}<.05)$.

The results of the Mann Whitney-U test for the personal hygiene and hygiene levels of the students are given in Table 10 according to the condition that all family members use the same towel.

Table 10. Mann Whitney-U test results of attitudes towards personal cleaning and hygiene levels according to the condition of all family members using the same towel

\begin{tabular}{cccccccc}
\hline Situation & $\mathrm{N}$ & $\mathrm{X}$ & $\mathrm{Ss}$ & Sequence average & Sequence total & $\mathrm{U}$ & $\mathrm{p}$ \\
\hline Yes & 277 & 26.57 & 3.472 & 526.36 & 145801.5 & & \\
No & 1023 & 27.96 & 2.813 & 684.11 & 699848.5 & & .000 \\
\hline
\end{tabular}

Table 10 when examined, it was found that the Mann Whitney-U test for the personal hygiene and cleaning levels of students who did not use the same towels with family members was statistically significantly higher than the other students $(\mathrm{p}<.05)$.

The results of the Mann Whitney-U test for the personal hygiene and cleanliness levels of the students are given in Table 11 according to the adequacy of the education provided in the school in terms of cleanliness and hygiene.

Table 11. Mann Whitney-U test results on cleaning and hygiene levels according to the adequacy of the school education in cleaning and hygiene issues

\begin{tabular}{cccccccc}
\hline Situation & $\mathrm{N}$ & $\mathrm{X}$ & $\mathrm{Ss}$ & Sequence average & Sequence total & $\mathrm{U}$ & $\mathrm{p}$ \\
\hline Yes & 310 & 27.02 & 3.021 & 277.60 & 86057.5 & & \\
No & 299 & 27.98 & 2.884 & 333.40 & 99687.5 & & \\
\hline
\end{tabular}


Table 11 when examined, Mann Whitney-U test results for personal hygiene and hygiene levels of students who study at school on cleanliness and hygiene are not sufficient for this education are statistically significant $(p<.05)$ and it was determined that the personal cleaning and hygiene levels of the students who stated that the education was not sufficient were higher.

The Mann Whitney-U test results for the personal hygiene and hygiene levels of the students are included in the Table 12 according to the condition of wanting to study at school in cleaning and hygiene issues who do not attend school.

Table 12. Mann Whitney-U test results for personal cleansing and hygiene levels according to the condition of wanting to study at school in cleaning and hygiene issues

\begin{tabular}{cccccccc}
\hline Situation & $\mathrm{N}$ & $\mathrm{X}$ & $\mathrm{Ss}$ & Sequence average & Sequence total & $\mathrm{U}$ & $\mathrm{p}$ \\
\hline Yes & 618 & 27.93 & 3.030 & 354.18 & 218886.0 & & \\
No & 73 & 26.90 & 2.968 & 276.71 & 20200.0 & & \\
\hline
\end{tabular}

Table 12 examined, cleaning and hygiene levels of students, who are not trained in cleaning and hygiene at school and who want to be given training, are statistically significantly higher than other students according to Mann Whitney-U test results $(\mathrm{p}<.05)$.

The answers given to the question by students who are trained at different class levels "What comes to your mind when it comes to cleanliness?" are given in Table 13.

Table 13. Answers to the question according to the level of class they study, "What comes to mind about cleaning"

\begin{tabular}{|c|c|c|c|c|c|c|c|c|c|c|}
\hline \multirow{2}{*}{ What comes to mind } & \multicolumn{2}{|c|}{ 5.class } & \multicolumn{2}{|c|}{ 6. class } & \multicolumn{2}{|c|}{ 7. class } & \multicolumn{2}{|c|}{ 8. class } & \multicolumn{2}{|c|}{ Total } \\
\hline & $\mathrm{f}$ & $\%$ & $\mathrm{f}$ & $\%$ & $\mathrm{f}$ & $\%$ & $\mathrm{f}$ & $\%$ & $\mathrm{f}$ & $\%$ \\
\hline To be healthy & 129 & 13.7 & 195 & 24.8 & 145 & 19.7 & 223 & 25.1 & 692 & 20.6 \\
\hline Dirty, non-stained & 172 & 18.2 & 129 & 16.4 & 148 & 20.1 & 180 & 20.2 & 629 & 18.7 \\
\hline The environment cleaning & 116 & 12.3 & 100 & 12.7 & 100 & 13.6 & 95 & 10.7 & 411 & 12.2 \\
\hline Daily cleaning & 105 & 11.1 & 69 & 8.8 & 80 & 10.9 & 49 & 5.5 & 303 & 9.0 \\
\hline Hygiene & 91 & 9.6 & 70 & 8.9 & 66 & 9.0 & 27 & 3.0 & 254 & 7.6 \\
\hline Purification of germs & 41 & 4.3 & 65 & 8.3 & 43 & 5.8 & 65 & 7.3 & 214 & 6.4 \\
\hline Hand-face cleaning & 96 & 10.2 & 4 & 0.5 & 44 & 6.0 & 64 & 7.2 & 208 & 6.2 \\
\hline My own personal cleansing & 62 & 6.6 & 33 & 4.2 & 39 & 5.3 & 48 & 5.4 & 182 & 5.4 \\
\hline Body cleaning & 57 & 6.0 & 38 & 4.8 & 0 & 0.0 & 41 & 4.6 & 136 & 4.1 \\
\hline Cleaning products & 23 & 2.4 & 19 & 2.4 & 21 & 2.8 & 19 & 2.1 & 82 & 2.4 \\
\hline A non-bacterial field & 0 & 0.0 & 19 & 2.4 & 25 & 3.4 & 30 & 3.4 & 74 & 2.2 \\
\hline Brushing my teeth & 25 & 2.6 & 21 & 2.7 & 0 & 0.0 & 16 & 1.8 & 62 & 1.8 \\
\hline Refreshment & 6 & 0.6 & 0 & 0.0 & 0 & 0.0 & 29 & 3.3 & 35 & 1.0 \\
\hline Nothing comes to my mind & 16 & 1.7 & 8 & 1.0 & 9 & 1.2 & 2 & 0.2 & 35 & 1.0 \\
\hline Meticulousness & 0 & 0.0 & 16 & 2.0 & 0 & 0.0 & 0 & 0.0 & 16 & 0.5 \\
\hline Cleaning of my own belongings & 4 & 0.4 & 0 & 0.0 & 9 & 1.2 & 0 & 0.0 & 13 & 0.4 \\
\hline Being regular & 2 & 0.2 & 0 & 0.0 & 8 & 1.1 & 0 & 0.0 & 10 & 0.3 \\
\hline Many things & 0 & 0.0 & 0 & 0.0 & 0 & 0.0 & 1 & 0.1 & 1 & 0.0 \\
\hline
\end{tabular}

The answers given by the students who received education at different grade levels to the question "What do you think about when you think of hygiene" are listed in Table 14. 
Table 14. According to the level of education they study "What do you think about when you think of hygiene" answers to their question

\begin{tabular}{lcccccccccc}
\hline \multirow{2}{*}{ What comes to mind } & \multicolumn{3}{c}{5. class } & \multicolumn{2}{c}{ 6.class } & \multicolumn{2}{c}{ 7.class } & \multicolumn{2}{c}{ 8.class } & \multicolumn{2}{c}{ Total } \\
\cline { 2 - 11 } & $\mathrm{f}$ & $\%$ & $\mathrm{f}$ & $\%$ & $\mathrm{f}$ & $\%$ & $\mathrm{f}$ & $\%$ & $\mathrm{f}$ & $\%$ \\
\hline Cleaning & 162 & 20.1 & 141 & 16.4 & 195 & 26.9 & 157 & 22.4 & 655 & 21.2 \\
To be healthy & 173 & 21.4 & 201 & 23.3 & 128 & 17.7 & 144 & 20.5 & 646 & 20.9 \\
Dirty, non-stained & 123 & 15.2 & 181 & 21.0 & 86 & 11.9 & 92 & 13.1 & 482 & 15.6 \\
Purification of germs & 99 & 12.3 & 94 & 10.9 & 105 & 14.5 & 135 & 19.2 & 433 & 14.0 \\
The environment cleaning & 60 & 7.4 & 36 & 4.2 & 0 & 0.0 & 33 & 4.7 & 129 & 4.2 \\
Body cleaning & 48 & 5.9 & 29 & 3.4 & 35 & 4.8 & 5 & 0.7 & 117 & 3.8 \\
Refreshment & 0 & 0.0 & 47 & 5.5 & 21 & 2.9 & 48 & 6.8 & 116 & 3.7 \\
Daily cleaning & 22 & 2.7 & 2 & 0.2 & 41 & 5.7 & 50 & 7.1 & 115 & 3.7 \\
Hand-face cleaning & 33 & 4.1 & 27 & 3.1 & 47 & 6.5 & 0 & 0.0 & 107 & 3.5 \\
Cleaning products & 58 & 7.2 & 25 & 2.9 & 22 & 3.0 & 0 & 0.0 & 105 & 3.4 \\
Fresh air & 9 & 1.1 & 14 & 1.6 & 21 & 2.9 & 14 & 2.0 & 58 & 1.9 \\
Nothing comes to my mind & 17 & 2.1 & 9 & 1.0 & 7 & 1.0 & 8 & 1.1 & 41 & 1.3 \\
My own personal cleansing & 0 & 0.0 & 27 & 3.1 & 0 & 0.0 & 9 & 1.3 & 36 & 1.2 \\
Many things & 0 & 0.0 & 12 & 1.4 & 13 & 1.8 & 0 & 0.0 & 25 & 0.8 \\
Being regular & 3 & 0.4 & 4 & 0.5 & 4 & 0.6 & 7 & 1.0 & 18 & 0.6 \\
Clean dress up & 0 & 0.0 & 12 & 1.4 & 0 & 0.0 & 0 & 0.0 & 12 & 0.4 \\
Meticulousness & 0 & 0.0 & 0 & 0.0 & 0 & 0.0 & 0 & 0.0 & 0 & 0.0 \\
\hline
\end{tabular}

The answer to the question "What comes to mind when you are called personal hygiene" is included in the Table 15 of students who are trained at different class levels.

Table 15. The answers they give to the question "What comes to mind when you're called personal hygiene" according to the class level of education

\begin{tabular}{lcccccccccc}
\hline \multirow{2}{*}{ What comes to mind } & \multicolumn{3}{c}{5. class } & \multicolumn{2}{c}{6. class } & \multicolumn{2}{c}{7. class } & \multicolumn{2}{c}{ 8.class } & \multicolumn{2}{c}{ Total } \\
\cline { 2 - 10 } & $\mathrm{f}$ & $\%$ & $\mathrm{f}$ & $\%$ & $\mathrm{f}$ & $\%$ & $\mathrm{f}$ & $\%$ & $\mathrm{f}$ & $\%$ \\
\hline Body cleaning & 155 & 18.4 & 183 & 30.7 & 83 & 12.2 & 57 & 8.3 & 478 & 17.0 \\
Clean dress up & 80 & 9.5 & 46 & 7.7 & 102 & 15.0 & 36 & 5.2 & 264 & 9.4 \\
Cleaning & 85 & 10.1 & 58 & 9.7 & 66 & 9.7 & 41 & 6.0 & 250 & 8.9 \\
My own personal cleansing & 40 & 4.7 & 36 & 6.0 & 53 & 7.8 & 120 & 17.5 & 249 & 8.9 \\
Fresh air & 86 & 10.2 & 30 & 5.0 & 52 & 7.6 & 80 & 11.6 & 248 & 8.8 \\
Daily cleaning & 68 & 8.1 & 50 & 8.4 & 93 & 13.7 & 17 & 2.5 & 228 & 8.1 \\
Purification of germs & 44 & 5.2 & 0 & 0.0 & 74 & 10.9 & 66 & 9.6 & 184 & 6.6 \\
The environment cleaning & 41 & 4.9 & 29 & 4.9 & 35 & 5.1 & 44 & 6.4 & 149 & 5.3 \\
Hand - face cleaning & 0 & 0.0 & 33 & 5.5 & 10 & 1.5 & 103 & 15.0 & 146 & 5.2 \\
My belongings & 50 & 5.9 & 41 & 6.9 & 8 & 1.2 & 42 & 6.1 & 141 & 5.0 \\
Being regular & 37 & 4.4 & 21 & 3.5 & 47 & 6.9 & 0 & 0.0 & 105 & 3.7 \\
Brushing my teeth & 44 & 5.2 & 23 & 3.9 & 14 & 2.1 & 19 & 2.8 & 100 & 3.6 \\
I change my socks & 44 & 5.2 & 17 & 2.9 & 14 & 2.1 & 19 & 2.8 & 94 & 3.3 \\
I do a lot of things & 26 & 3.1 & 18 & 3.0 & 23 & 3.4 & 21 & 3.1 & 88 & 3.1 \\
Cleaning products & 26 & 3.1 & 2 & 0.3 & 0 & 0.0 & 20 & 2.9 & 48 & 1.7 \\
Nothing comes to my mind & 17 & 2.0 & 9 & 1.5 & 7 & 1.0 & 2 & 0.3 & 35 & 1.2 \\
\hline
\end{tabular}

The answers given by the students who study at different class levels to the question of "What kind of practices do you perform in order to provide personal hygiene in one day?" took place in Table 16. 
Table 16. The answer to the question according to the level of the class they are studying, "What kind of practices do you do to ensure your personal hygiene in one day?"

\begin{tabular}{lcccccccccc}
\hline \multirow{2}{*}{ Applications } & \multicolumn{2}{c}{5. class } & \multicolumn{2}{c}{6. .class } & \multicolumn{2}{c}{7. class } & \multicolumn{2}{c}{8 .class } & \multicolumn{2}{c}{ Total } \\
\cline { 2 - 11 } & $\mathrm{f}$ & $\%$ & $\mathrm{f}$ & $\%$ & $\mathrm{f}$ & $\%$ & $\mathrm{f}$ & $\%$ & $\mathrm{f}$ & $\%$ \\
\hline My own personal cleansing & 238 & 28.3 & 221 & 31.4 & 212 & 32.3 & 257 & 30.1 & 928 & 30.4 \\
I wash my hand- face & 103 & 12.2 & 95 & 13.5 & 54 & 8.2 & 73 & 8.5 & 325 & 10.6 \\
Nothing comes to my mind & 53 & 6.3 & 80 & 11.4 & 59 & 9.0 & 67 & 7.8 & 259 & 8.5 \\
I do cleaning & 80 & 9.5 & 64 & 9.1 & 49 & 7.5 & 48 & 5.6 & 241 & 7.9 \\
I clean my belongings & 57 & 6.8 & 48 & 6.8 & 49 & 7.5 & 62 & 7.3 & 216 & 7.1 \\
I comb my hair & 48 & 5.7 & 31 & 4.4 & 33 & 5.0 & 71 & 8.3 & 183 & 6.0 \\
I clean my body & 44 & 5.2 & 14 & 2.0 & 40 & 6.1 & 71 & 8.3 & 169 & 5.5 \\
I brush my teeth & 87 & 10.3 & 1 & 0.1 & 36 & 5.5 & 45 & 5.3 & 169 & 5.5 \\
I get dressed clean & 51 & 6.1 & 22 & 3.1 & 18 & 2.7 & 78 & 9.1 & 169 & 5.5 \\
I try to purify the microbes & 48 & 5.7 & 24 & 3.4 & 31 & 4.7 & 30 & 3.5 & 133 & 4.4 \\
I protect my health & 13 & 1.5 & 41 & 5.8 & 32 & 4.9 & 19 & 2.2 & 105 & 3.4 \\
I use cleaning products & 6 & 0.7 & 16 & 2.3 & 15 & 2.3 & 22 & 2.6 & 59 & 1.9 \\
I cut my nails & 14 & 1.7 & 9 & 1.3 & 7 & 1.1 & 2 & 0.2 & 32 & 1.0 \\
I'm organized & 0 & 0.0 & 16 & 2.3 & 0 & 0.0 & 9 & 1.1 & 25 & 0.8 \\
I change my socks & 0 & 0.0 & 0 & 0.0 & 21 & 3.2 & 0 & 0.0 & 21 & 0.7 \\
I do a lot of things & 0 & 0.0 & 21 & 3.0 & 0 & 0.0 & 0 & 0.0 & 21 & 0.7 \\
\hline
\end{tabular}

\section{Discussion}

In the study, it was determined that the students' cleaning and hygiene levels were high. The effect of the parents of the students to warn the students to pay attention to cleanliness and hygiene is observed. It is thought that all students form the same social environment, the students perform equivalent daily life activities, and the hygiene and cleanliness habits are positively influenced.

The result of the research shows similarities with the research done by Önsüz and Hıdıroğlu (2008). The results of the research show that secondary school students have gained hygiene and cleanliness habits. However, in the study of Kahveci and Demirtaş (2012), it was concluded that high school students 'perceptions of cleanliness and hygiene were very low.

It was observed that the level of personal hygiene and cleanliness of the students according to their gender did not differ statistically significantly. The results differ from findings in the study of Kahveci and Demirtaş (2012), Kaya et al. (2006) and Tahiroğlu (2011), which determines the hygiene score of male students as lower than the hygiene score of female students. However, it is similar to the findings in Aslan et al. (2006), Karaoğlu and Pehlivan (1997) and Şimşek et al.'s (2010)'s research.

As a result of the research carried out by Kırım and Hırça (2015), it was concluded that the dissemination of health education in schools, science programs and the support of teachers in the development of Public Health level will contribute to the growth of healthy students and thus to the formation of a healthy society. Coşkun and Kara (2015) determined that the positive behavioural changes of the students after the health education given to secondary school students were less than the increase in knowledge levels. As behavioral change requires a longer period of time, health education at schools should be repeated periodically and educators should support their students with positive cleaning and hygiene behavior. The result of the research, $89.4 \%$ of the students who do not receive education in the field of cleaning and hygiene in their schools want to be educated in the field of cleaning and hygiene in their schools. General cleaning and hygiene levels of students who are educated in their schools about cleaning and hygiene are significantly higher than other students. This result is similar to the research of the Kalınc1 (2006).

Health education programs should be developed in order to create positive behavioural changes in the students concerned with personal hygiene. Due to the great effect of the education status of the families in the personal hygiene behaviors as a result of the researches, it is of great importance to educate the families with the training programs on personal hygiene (Şimşek et al., 2010). It is observed that the students' levels of cleanliness and hygiene according to their mothers' educational levels differ statistically. General cleaning and hygiene levels of students whose mother is a graduate of secondary school, high school and university are significantly higher than students whose mother is non-literate. Köse et al. (2010)'s research with similar age group also supports the results of this research. 
According to the education levels of the students' fathers, there are significant differences in the level of personal cleansing and hygiene. The level of cleanliness and hygiene of students whose father graduated from primary school, secondary school, high school and university are significantly higher than the students whose father are non-literate. Thanks to this finding, it is thought that the increase in the literacy rate of the family increases the cleaning and hygiene habits of the students positively. Kurt et al. (2008)'s research showed that there was no significant correlation between the levels of father and mother education, but it was observed that the findings obtained by Kalınc1 (2006) carried similar results with the research and supported the results of the research.

Cleaning and hygiene levels of students who regularly clean bedrooms and other rooms at home are significantly higher than other students. When individual gains hygiene and cleanliness habits, he/she can improve the quality of life by converting him/her into behavior in his/her environment. It can be said that individuals in a clean and hygienic environment pay more attention to their personal hygiene.

In this study, it was observed that reminding parents about dental cleaning and hygiene had positive effects on the students and gave positive results. In the literature, it is stated that it is important for children to have a family model in their positive behavior such as brushing teeth (Astrom \& Jakobsen, 1996).

Interestingly, as the number of individuals in the family increased, a significant increase was observed in the cleaning and hygiene habits of the students. More importance is given to cleanliness and hygiene habits in crowded families can be said as a result of this research.

As a result, students' general cleaning and hygiene levels are high. It can be said that individuals in a clean and hygienic environment pay more attention to their personal hygiene. Everyone can comment on personal hygiene, cleaning and health promotion, but when it is said "What is cleaning, hygiene and personal hygiene?", it is seen that everyone has made individual definitions of their own. The educational status of the parents has an important place in the cleaning, hygiene and personal hygiene habits of the students. As the literacy rate in the family increased, the students' cleaning and hygiene habits increased positively as a result of the research.

\section{Recommendations}

In the light of the findings obtained as a result of the research and the relevant literature, the following suggestions can be made;

As a result of the research, it is of great importance that students' families should be educated on cleanliness and personal hygiene as a result of the obvious effect of families on cleanliness and personal hygiene behavior. Education programmes can be developed to ensure that families are conscious and knowledgeable about cleanliness and hygiene. Educational books, school journals, public spots, sketches prepared at the parents' meetings, orotoriums and school newspapers can be prepared for this purpose. In the future, every positive hygiene and cleaning habits that will be given to the students' families will provide the basis for a healthy generation that correctly implements the hygiene and cleanliness behaviors.

Activities can be prepared for cleaning and personal hygiene practices in guidance and club activities in order to improve the hygiene and hygiene habits of the students in a positive way and to maintain their health. Projects can be organized for cleaning and personal hygiene habits in community service practices.

In order to prevent the cleaning and hygiene habits of students of this age to be forgotten and forgotten, the related subjects must be repeated and reminded. In schools, proper cleaning and hygiene behaviors should be reminded by seminars, theaters, conferences and showing public spots with certain periods.

\section{References}

Allison, M. A., Crane, L. A., Beaty, B. L., Davidson, A. J., Melinkovich, P., \& Kepme A. (2007). School-Based Health Centers: Improving Access and Quality of Care for Low-Income Adolescents. Pediatrics, 120, 887-894. https://doi.org/10.1542/peds.2006-2314

Arat, A. (2013). Yatılı İlkögretim Bölge Okulu 1. Kademe Öğrencilerinin Kişisel Hijyen Uygulamaları (Master thesis, Ankara: Gazi Üniversitesi, Eğitim Bilimleri Enstitüsü).

Aslan, D., Mermerkaya, U., Kaya, E., Kaya, H., Esen, E., Koban, Y., \& Pekcan, H. (2006). Ankara'da Bir İlköğretim Okulunda El Yıkama Konusunda Yapılmış Olan Bir Müdahale Çalışması. Türkiye Klinikleri J Med Sci Dergisi, 26, 157-162. file:///C:/Users/EG\%C4\%B0T\%C4\%B0M/Downloads/tipbil26-2-8.pdf

Astrom, A., \& Jakobsen, R. (1996). The Effect of Parental Dental Health Behavior on That of Their Adolescent Offspring. Acta Odontol Scand, 54, 235-241. https://doi.org/10.3109/00016359609003530

Aydın, A. (1996). Okul Çă̆ı Çocuklarının Beslenme, A ̆ğı ve Genel Vücut Hijyenine İlişkin Uygulamaları ve Var 
Olan Sağlık Sorunlarının Belirlenmesi (Master thesis, Ankara: Hacettepe Üniversitesi, Sağlık Bilimleri Enstitüsü).

Balaban, M. (2011). Okul Öncesi Dönemde Hijyen Alışkanlı̆̆ı Kazandırma Ĕ̆itim Programının Çocukların Hijyen Davranışlarına Etkisini İncelenmesi (Master thesis, Bolu: Abant İzzet Baysal Üniversitesi, Sosyal Bilimler Enstitüsü).

Bebiş, H. (1997). Hemşire Öğrencilerin Kişisel Hijyen Bilgi ve Uygulamalarının Belirlenmesi (Master thesis, Ankara: Gata Sağlık Bilimleri Enstitüsü).

Bilici, S., Uyar, M. F., Beyhan, Y., \& Sağlam, F. (2008). İlköğretim Çocukları İ̧̧in Gıda Hijyeni El Kitabı. Ankara: Klasmat Matbaacılık.

Büyüköztürk, Ş. (2017). Sosyal Bilimler İçin Veri Analizi El Kitabı. Ankara: Pegem Akademi.

Coşgun, M., \& Kara, F. (2015). Öğrencilere Verilen Sağlık Eğitiminin Bilgi ve Davranışlarına Etkisinin Değerlendirilmesi. Sted Dergisi, 24(2), 55-63.

Eraslan, B. (2009). Stnıf Öğretmenliği Öğrencilerinin, Sik Görülen Bulaşıcı Hastalıklar İle İlgili Bilgi Düzeylerinin ve Sağllğı Koruma Davranışlarının Değerlendirilmesi (Master thesis, Adana: Çukurova Üniversitesi, Sosyal Bilimler Enstitüsü).

Güler, G., \& Kubilay, G. (2004). Bir İlköğretim Okulu Öğrencilerinin Fiziksel Bakım Sorunlarının Belirlenmesi. C. U. Tip Fakültesi Dergisi, 26(2), 60-65. http://eskidergi.cumhuriyet.edu.tr/makale/890.pdf

Igoe, J. B., \& Speer, S. (1996) Community Health Nurse İn The Schools. In M. Stanhope, J. Lancaster (Eds.), Community Health Nursing. Boston: Mosby.

Kahveci, G., \& Demirtaş, Z. (2012). İlköğretim Okulu 6, 7, ve 8. Sınıf Öğrencilerinin Temizlik ve Hijyen Algıları. Pegem Eğitim ve Öğretim Dergisi, 2(2), 51-61. Retrieved from http://dergipark.gov.tr/download/article-file/209696

Kalınc1, N. (2006). Zonguldak İl Merkezi İlköğretim 5.Sinıf Öğrencilerinin El Hijyenine Yönelik Davranışlarının Belirlenmesi (Master thesis, Zonguldak: Zonguldak Karaelmas Üniversitesi, Sağlık Bilimleri Enstitüsü).

Karadon, H. D. (2010). İlköğretim 7. Sınıf Öğrencilerinin Mikroorganizmalar Hakkındaki Temel Bilgi ve Görüşlerinin Araştırılması ve Hijyen Eğitimi Sürecindeki Önemi (Master thesis, Muğla: Muğla Üniversitesi, Fen Bilimleri Enstitüsü).

Karaoğlu, L., \& Pehlivan, E. (1997). Malatya Il Merkezinde Farklı Programlardaki Lise Son Sınıf Öğrencilerinin Sağlıkla İlgili Bilgi, Tutum ve Uygulamalarının İncelenmesi. Turgut Özal Tip Dergisi, 2(2), 391-397.

Kaya, M., Büyükşerbetçi, M., Meriç, M. B., Çelebi, A. E., Boybeyi, Ö., Işık, A., ... Güler, Ç. (2006). Ankara'da Bir Lisenin 9. ve 10. Sınıf Öğrencilerinin Kişisel Hijyen Konusunda Davranışlarının Belirlenmesi. Sürekli Tip Ë̆itimi Dergisi, 15(10), 167-171.

Kırım, C., \& Hırça, N. (2015). Lise Öğrencilerinin Kişisel Hijyen ve Temizlik Alışkanlıklarının Fen Okur-Yazarlığına Göre Değerlendirilmesi. Bartın Üniversitesi Eğitim Fakültesi Dergisi, 4(2), 790-802. https://doi.org/10.14686/buefad.v4i2.5000138700

Kitiş, Y., \& Bilgili, N. (2011). İlköğretim Öğrencilerinde El Hijyeni ve El Hijyeni Eğitiminin Etkinliğinin Değerlendirilmesi. Maltepe Üniversitesi Hemşirelik Bilim ve Sanatı Dergisi, 4(1), 93-102.

Köse S., Güven S., Mert E., Eraslan E., \& Esen S. (2010). 12-13 Yaş Grubu Çocuklarda Oral Hijyen Eğitiminin Etkinliği. Anadolu Hemşirelik Ve Sağllk Bilimleri Dergisi, 13(4), 44-52. http://dergipark.gov.tr/download/article-file/29562

Kurt, Ö., Kayran, Y., Zengin, S., Vural, G., Dilsizoğlu, D., Kalalı, E., Aydın, K., \& Buğdayc1, R., (2008). Mersin İl Merkezinde İlköğretim Birinci ve Altıncı Sınıf Öğrencilerinde Temel Sağlık Davranışlarının Değerlendirirlmesi: Okul Tabanlı Kesitsel Bir Çalışma. Mersin Üniversitesi Sağllk Bilim Dergisi, 1(2), 19-25. Retrieved from http://dergipark.gov.tr/download/article-file/182689

Önsüz, M. F., \& Hıdıroğlu, S. (2008). İstanbul'da Farklı İki İlköğretim Okulundaki Öğrencilerin Kişisel Hijyen Alışkanlıklarının Belirlenmesi. Adnan Menderes Üniversitesi Tip Fakültesi Tip Dergisi, 9(1), 9-17.

Şanlı, N., Topyürek, Ş., \& Güngen, Y. (2002). Ev ve Ailede Yaşam Yönetimi. Ankara: Başak Matbaacılık.

Şimşek, Ç., Piyal, B., Tüzün, H., Çakmak, D., Turan, H., \& Seyrek, V. (2010). Ankara İl Merkezindeki Bazı Lise Öğrencilerinde Kişisel Hijyen Davranışları. Taf Preventive Medicine Bulletin, 9(5), 433-440. Retrieved from https://www.ejmanager.com/mnstemps/1/1-1288306436.pdf 
Şimşek, D. (2012). İlköğretim Birinci Sinıf Öğrencilerine Verilen Planlı El Ylkama Ĕgitiminin El Ylkama Davranışı Üzerine Etkisinin Belirlenmesi (Master thesis, Ankara: Başkent Üniversitesi, Sağlık Bilimleri Enstitüsü).

Tahiroğlu, M. (2011). İlköğretim 4. Sinıf Sosyal Bilgiler Dersinde Doğa Sevgisi, Temizlik ve Sağllklı Olma Değerlerinin Öğretimi ve Değerlere İlişsin Öğrenci Tutumlarının Belirlenmesi (Ph. D. thesis, Ankara: Gazi Üniversitesi, Eğitim Bilimleri Enstitüsü).

Tartaç, Y. (2007). Bir Kız Meslek Lisesi Öğrencilerinin Kişisel Hijyenle İlgili Allşkanlıklarının Belirlenmesi ve Yapılan Eğitim Sonrası, Ĕ̈itimin Etkinliğinin Değerlendirilmesi (Master thesis, Ankara: Gazi Üniversitesi, Sağlık Bilimleri Enstitüsü).

WHO (World Health Organisation). (1996). Strengthening Interventions To Reduce Helminth Infections As An Entry Point For The Development Of Health Promoting Schools. Geneva: World Health Organisation, (Document Hpr/Hep/96.10).

Yetkin, A., \& Yiğitbaş Ç. (2008). Sağlık Yüksekokulu Birinci ve Dördüncü Sınıf Öğrencilerinin Bireysel Hijyen İle İlgili Alışkanlıklarının Karşılaştırılması. Atatürk Üniversitesi Hemşirelik Yüksekokulu Dergisi, 11(2), 72-84. http://dergipark.gov.tr/download/article-file/29411

\section{Note}

Note 1 . This article was produced from a master's thesis titled "Determining secondary school students awareness and attitudes towards cleanliness and hygiene".

\section{Copyrights}

Copyright for this article is retained by the author(s), with first publication rights granted to the journal.

This is an open-access article distributed under the terms and conditions of the Creative Commons Attribution license (http://creativecommons.org/licenses/by/4.0/). 